$1-1-1976$

\title{
Some microbiological factors associated with surface-mine reclamation
}

\author{
H. A. Wilson \\ David A. Zuberer
}

Follow this and additional works at: https://researchrepository.wvu.edu/ wv_agricultural_and_forestry_experiment_station_bulletins

\section{Digital Commons Citation}

Wilson, H. A. and Zuberer, David A., "Some microbiological factors associated with surface-mine reclamation" (1976). West Virginia Agricultural and Forestry Experiment Station Bulletins. 645T.

https://researchrepository.wvu.edu/wv_agricultural_and_forestry_experiment_station_bulletins/719 @ WVU. It has been accepted for inclusion in West Virginia Agricultural and Forestry Experiment Station Bulletins by an authorized administrator of The Research Repository @ WVU. For more information, please contact ian.harmon@mail.wvu.edu. 


\section{Some Microbiological Factors Associated with Surface-Mine Reclamation}

Bulletin 645T June 1976

West Virginia University Agricultural Experiment Station

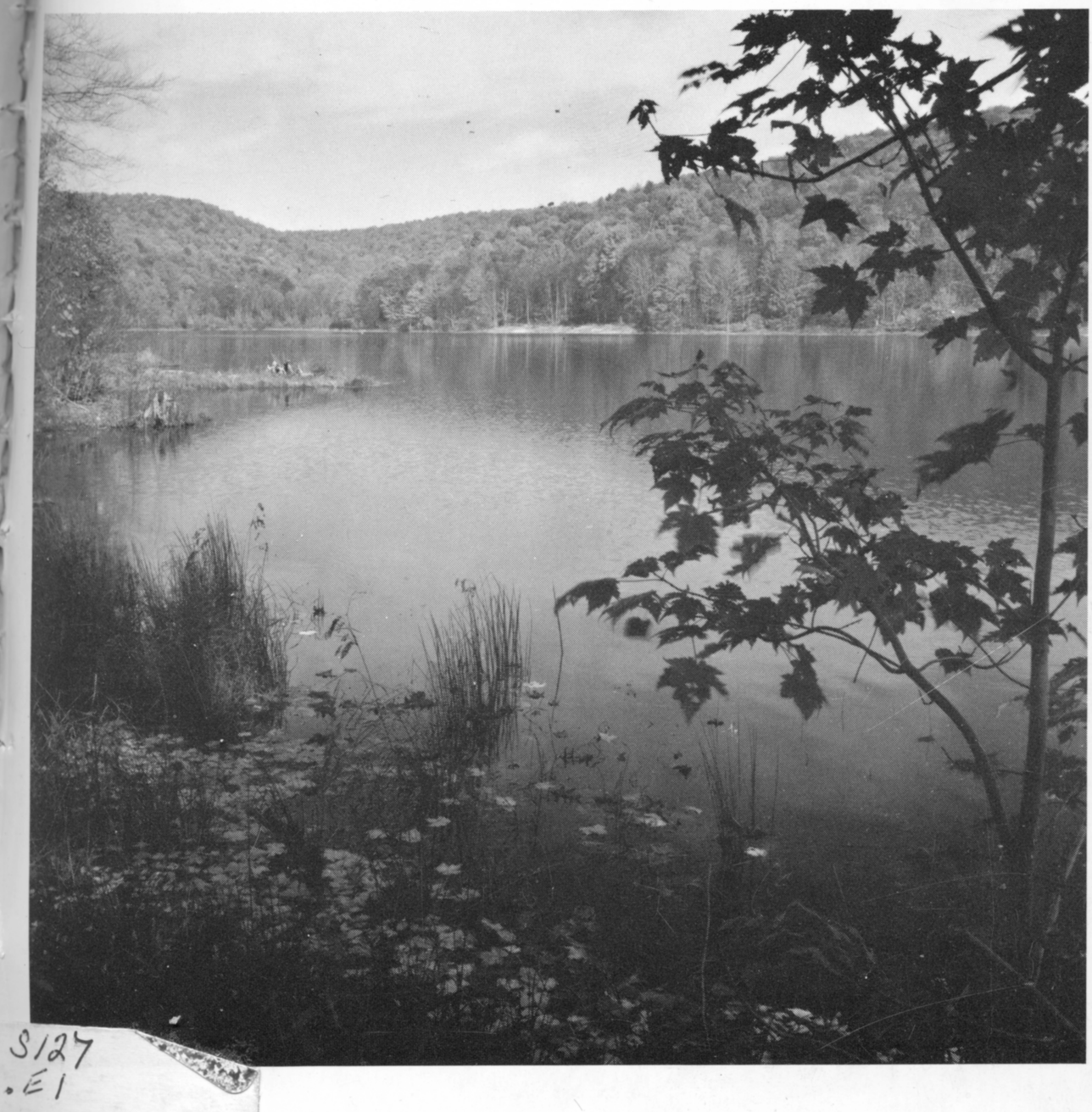




\title{
ACKNOWLEDGMENTS
}

The authors thank all persons involved in the preparation of this manuscript, and in particular Dr. R. M. Smith for his guidance on the geological aspects of this bulletin.

We also thank the Federal Water Pollution Control Administration (Project 14010 EJE) for the funding which made this work possible.

\section{THE AUTHORS}

David A. Zuberer is a former graduate student in Plant Pathology whose present address is University of Southern Florida, Tampa, and H. A. Wilson is Bacteriologist Emeritus, West Virginia University Agricultural Experiment Station.

\author{
West Virginia University \\ Agricultural Experiment Station \\ College of Agriculture and Forestry \\ Dale W. Zinn, Director \\ Morgantown
}




\section{Contents}

Introduction ................... 1

Materials and Methods

Materials

Sandstone ....................... 4

Deep-mine refuse (tailings) . . . . . . . . . . 4

Coal ...................... 4

Pyrite ................... 4

Methods

Acid production from selected mine-spoil material . . . . . . . 4

Acid production from calcareous and noncalcareous sandstone . . . . 5

Manometric studies . . . . . . . . . . . 5

Effect of buried depth on the oxidation of pyrite . . . . . . 6

Results

Acid Production from Selected Mine-spoil Materials . . . . . . . . 7

Acid Production from Calcareous and Noncalcareous Sandstone . . . . . 9

Manometric Studies. . . . . . . . . . . . . . 9

Effect of Burial Depth on the Oxidation of Pyrite . . . . . . . 11

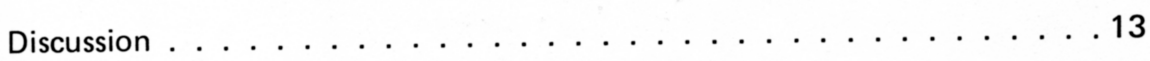

Literature Cited . . . . . . . . . . . . . . . 19 


\section{ABSTRACT}

Several pyritic mine-spoil materials were studied in relation to microbial acid production. Some, but not all, of the pyritic shales and sandstones were effective in promoting acid conditions. Burial of the pyritic materials deeply below the soil surface was effective in suppressing acid generation from them.

It has been demonstrated that liming of acid spoils and standing spoil materials discourages growth of the bacteria involved in the formation of acid drainage. There are indications that microbial acid production is of little importance in sandstones of low sulfur (pyrite) content.

It is recommended that pyritic materials be placed as deeply as possible below the soil surface upon regrading. To obtain a $\mathrm{pH}$ unfavorable to the activities of the autotrophic iron and sulfur oxidizing bacteria, heavy liming of spoil materials during mining and upon replacement is recommended. 


\title{
Some Microbiological Factors Associated with Surface-Mine Reclamation
}

\author{
H. A. Wilson and David A. Zuberer
}

\section{Introduction}

Acid mine drainage is one of the predominant pollution problems in West Virginia and surrounding states. This drainage is characteristically high in ferrous-iron, sulfate, and hydrogen-ion content. The drainage results from the chemical and microbiological oxidations of pyritic mine spoil materials exposed during coal extractions both by surface- and deep-mining operations. Recent estimates indicate that some 3.5 million tons of sulfuric acid are added to streams and rivers each year. In the United States it has been estimated that 35 per cent of this discharge is associated with abandoned surface mines, 25 per cent with abandoned deep mines, and 40 per cent with active mining operations (7).

The oxidation of ferrous iron in acid drainage to ferric iron with subsequent deposition of iron hydroxides (also known as "yellow boy") creates several problems, including those associated with aesthetics. The drainage also leads to destruction of physical and biological aspects in affected streams.

Colmer and Hinkle (1) proved the oxidation of ferrous iron in acid mine drainage to be of a biological nature. By filter sterilizing fresh acid-drainage samples, they were able to show that the characteristic reddish-brown precipitate indicative of iron oxidation did not appear, thus indicating a lack of microbiological oxidation.

In 1950, Colmer, Temple, and Hinkle (2) reported isolating an iron-oxidizing bacterium from acid mine drainage of bituminous coal mines. Their results showed that ferrous iron was rapidly oxidized to the ferric state in the presence of the bacterium on thiosulfate medium. On the basis of its ability to oxidize thiosulfate, with the production of sulfuric acid, and its morphological characteristics, these workers suggested that the bacterium most closely resembled members of the genus Thiobacillus. At that time, they did not state that the bacterium was a chemolithotroph capable of utilizing iron as an energy source. 
Then, in 1951, Temple and Colmer (13) proved the oxidation of ferrous iron in acid drainage to be due to an autotrophic iron-oxidizing bacterium. The bacterium was grown on a medium containing ferrous sulfate and other mineral salts lacking any form of organic carbon. On the basis of the autotropism of the bacterium on both thiosulfate and ferrous sulfate media, they assigned the bacterium to the genus Thiobacillus, and suggested the species name Thiobacillus ferroxidans.

Leathen and Braley (6) later reported isolating a new iron-oxidizing bacterium. This organism was incapable of utilizing sulfur or thiosulfate as an energy source, thus they named the bacterium, which also was an autotroph, Ferrobacillus ferrooxidans. However, Silver (9) has reported growth of Ferro. bacillus ferrooxidans on elemental sulfur as well as some other sulfur compounds. These compounds included sulfide, thiosulfate, tetrathionate, sulfite, and dithionite. Potassium thiocyanate was not oxidized. In 1961, Unz and Lundgren (15) conducted a comparative nutritional study of the chemolithotrophic iron- and sulfur-oxidizing bacteria, T. ferrooxidans, F. ferrooxidans, and $T$. thiooxidans. Their results showed both $T$. ferrooxidans and $F$. ferrooxidans capable of oxidizing ferrous iron, and also that both of these bacteria could rapidly initiate sulfur oxidation even when previously cultured on a ferrous-iron medium. These researchers concluded that the organisms are nutritionally similar and that a reevaluation of the present classification is in order. Most recently, Kelly and Tuovinen (4) published a recommendation that the names Ferrobacillus ferrooxidans Leathen and Braley and Ferrobacillus sulfooxidans Kinzel (not mentioned above) be recognized as synonyms of Thiobacillus ferrooxidans Temple and Colmer.

Two different mechanisms for the microbial attack on sulfide minerals have been proposed (11). Silverman (10) refers to these mechanisms as the direct-contact mechanism and the indirect-contact mechanism. He states, "According to the indirect contact mechanism, ferric ions serve as the primary oxidant, oxidizing metal sulfides while being reduced in turn to the ferrous state. The bacteria then enter into the reaction by oxidizing ferrous iron to the ferric state, thereby regenerating the primary oxidant." This mechanism can be seen in the following reactions as proposed by Temple and Delchamps (14):

$$
\mathrm{FeS}_{2} \text { (pyrite) }+\mathrm{H}_{2} \mathrm{O}+31 / 2 \mathrm{O}_{2} \longrightarrow \mathrm{FeSO}_{4}+\mathrm{H}_{2} \mathrm{SO}_{4}
$$

Since the ferrous iron is stable in an acidic medium, the following reaction has been attributed to the activities of the iron oxidizing chemolithotrophic bacteria:

$$
2 \mathrm{FeSO}_{4}+1 / 2 \mathrm{O}_{2}+\mathrm{H}_{2} \mathrm{SO}_{4} \longrightarrow \mathrm{Fe}_{2}\left(\mathrm{SO}_{4}\right) 3+\mathrm{H}_{2} \mathrm{O}
$$

Ferric sulfate thus formed reacts with the pyrite so that ferric sulfate is reduced and pyrite is oxidized: 
Part or all of the ferric sulfate may be hydrolyzed to the basic ferric sulfate $\mathrm{Fe}(\mathrm{OH}) \mathrm{SO}_{4}$ or under actual conditions may go completely to ferric hydroxide $\mathrm{Fe}(\mathrm{OH})_{3}$. The "direct contact" mechanism, as the name implies, requires an intimate contact between the bacterium and the sulfide mineral under aerobic conditions (10).

Silverman (10) obtained results in accord with reaction III above when ferric sulfate was added to HC1-pretreated pyrite in the absence of bacteria; however, no elemental sulfur was recovered. He also reported the failure of a pyrite sample containing calcium carbonate $\left(\mathrm{CaCO}_{3}\right)$ to be oxidized by the bacteria. The same sample when treated with $\mathrm{HC} 1$ to remove the carbonates became susceptible to microbial oxidation. Silverman concluded that it is probable that both mechanisms, the indirect-contact mechanism and the direct-contact mechanism, operate simultaneously.

The literature cited previously gives adequate proof that the chemolithotrophic iron- and sulfur-oxidizing bacteria are intimately involved in the formation of acid mine drainage. Those same conditions that give rise to acid production in deep mines also give rise to the generation of acid on surface-mining operations.

Pyritic shales and sandstones as well as other sulfurous materials are common in the rock overlying some coal seams. Fracturing of the overburden and the coal seam itself makes conditions favorable for the development of the microorganisms involved by allowing an access of air and water and by creating a greater surface area for the microorganisms to attack (5). Such exposures of pyritic materials as are brought about by removal of overburden are significant because of large increases in oxidation with the subsequent acid production. These oxidations, however, are influenced by the nature of the ground waters and the surrounding rocks. Kuznetsov (5) states that " . . . if the host rocks, for example carbonates, neutralize the acids as they are formed, unfavorable conditions are produced for the development of Thiobacillus ferrooxidans which is, to judge from all available data, the principal organism that oxidizes sulfide."

The microbiology of strip-mine spoil has been investigated by Wilson (17). In his studies on several strip-mine spoils, he has reported isolating sulfur-oxidizing bacteria. Enumerations indicated a wide range in numbers present; however, there was a decrease in number when going from a mine spoil to an undisturbed soil. In two spoils studied, there was well over a hundredfold decrease in the numbers of sulfur oxidizers between the nonvegetated mine spoil and the undisturbed soil.

The literature dealing with revegetation of surface-mined lands is quite extensive. The reader is referred to reference (3) for a compilation of such literature, and to reference (8) for results of some revegetation studies. 


\section{MATERIALS AND METHODS}

\section{Materials}

Spoil materials used in these studies were associated with the overburden of the Upper Freeport coal seam being mined one mile south and one-half mile west of Valley Point in Preston County, West Virginia (16). The coal was from a reveg. etated mining site in Preston County. The deep-mine refuse was obtained at Norton, West Virginia, and the pyritic materials used in the lysimeter study were obtained from an old stripping operation at Canyon, Monongalia County, West Virginia.

\section{SANDSTONE}

The sandstones were of varying iron and sulfur contents. Euhedral pyrite was observable microscopically in all of the gray (low-chroma) sandstones. The low-chroma (high-sulfur) gray sandstone designated as the Lower Mahoning sandstone occurs over a thin-shale horizon (Uffington shale) above the Upper Freeport coal. The high-chroma (low-sulfur) weathered sandstone was above the low-chroma gray sandstone in the overall profile.

\section{DEEP-MINE REFUSE (TAILINGS)}

A sample of Kittanning deep-mine refuse from Norton, West Virginia, was included in some of the tests. It contained: 0.75 per cent sulfur, presumably partly organic; calcium, 240 lbs/1,000 tons; dilute acid extractable phosphorous, $35 \mathrm{lbs} / 1,000$ tons; 49.7 per cent volatile matter, presumably organic; and had a lime requirement of 0.75 ton $/ 1,000$ tons.

\section{COAL}

A coal sample known to contain 4 per cent sulfur in unknown forms was a third spoil material used in the study.

\section{PYRITE}

Pyrite used in the study to determine the effect of burial depth on the oxidation had been obtained earlier by the junior author and stored in the laboratory. This material contained 14.34 per cent iron oxide $\left(\mathrm{Fe}_{2} \mathrm{O}_{3}\right)$ and 31.3 per cent sulfur. It is probable that some of the sulfur was in an organic form.

\section{Methods}

\section{ACID PRODUCTION FROM SELECTED MINE-SPOIL MATERIAL}

To determine if acid would be produced from the mine-spoil materials, $250-\mathrm{ml}$ Erlenmeyer flasks containing $100 \mathrm{ml}$ of sterile $9 \mathrm{~K}$ mineral-salts solution (12) to which 2 grams of the substrate had been added were inoculated with fresh acid mine drainage or a pure culture of Thiobacillus ferrooxidans. The cultures were incubated at $25^{\circ} \mathrm{C}$ on a rotary shaker. Samples were withdrawn aseptically and $\mathrm{pH}$ was determined. Uninoculated flasks served as controls to measure any purely chemical oxidation that might occur. 


\section{ACID PRODUCTION FROM CALCAREOUS AND NONCALCAREOUS SANDSTONE}

To study the effect of carbonates on the oxidation of pyrite, as indicated by $\mathrm{pH}$, two series of sandstone of varying sulfur content-one with carbonates and the other without-were studied by the method outlined above. The samples used in this study are listed in Table 1. All of the samples were ground to pass through a 60-mesh sieve.

\section{MANOMETRIC STUDIES}

For manometric studies, the Hach B.O.D.* (biochemical oxygen demand) apparatus was employed. Four different substrates were compared as to their relative oxygen uptake during biological and nonbiological oxidations. The energy sources-which included 4 grams of gray Sewickley sandstone (SS-18) (gray: $N, 6 / 1$ ) with 18 per cent sulfur; 4 grams of coal, 4 per cent sulfur; 2 grams of ferrous iron as ferrous sulfate; and 2 grams of elemental sulfur-were each added to bottles containing $155 \mathrm{ml}$ of sterile $9 \mathrm{~K}$ mineral-salts solution. The spoil materials were ground to pass through a 60-mesh sieve.

\begin{tabular}{|lc|}
\hline \multicolumn{2}{|c|}{ 9K Mineral-Salts Solution } \\
Basal Salts \\
$\left(\mathrm{NH}_{4}\right)_{2} \mathrm{SO}_{4}$ & $3.0 \mathrm{~g}$ \\
$\mathrm{KC}$ & 0.10 \\
$\mathrm{~K}_{2} \mathrm{HPO}_{4}$ & 0.50 \\
$\mathrm{MgSO}_{4} .7 \mathrm{H}_{2} \mathrm{O}$ & 0.50 \\
$\mathrm{Ca}\left(\mathrm{NO}_{3}\right)_{2}$ & 0.01 \\
$\mathrm{H}_{2} \mathrm{O} \mathrm{Dist.}_{10 \mathrm{~N} \mathrm{SO}_{4}}$ & $700.00 \mathrm{ml}$ \\
$\mathrm{Energy}_{2}$ source & $1.0 \mathrm{ml}$ \\
$\mathrm{FeSO}$ & \\
& $300 \mathrm{ml}$ of a \\
& $14.74 \%(\mathrm{w} / \mathrm{v})$ \\
Elemental sulfur & solution \\
& $10 \mathrm{~g} / \mathrm{l}$ basal \\
& salt solution \\
\hline
\end{tabular}

*Hach Chemical Company, Ames, lowa. 
TABLE 1

Materials Used in Study to Determine Effects of Carbonates on Acid Production from Pyrite.

\begin{tabular}{llrc}
\hline \hline Sandstone & \multicolumn{1}{c}{ Munsell Color } & \% Total Sulfur \\
\hline Calcareous & & \\
UFA-34 & Grayish white & \\
UFA-35 & Light gray & $7.5 \mathrm{Y}, 7 / 1$ & 0.275 \\
& & & 0.720 \\
Noncalcareous & & & \\
UFA-9 & Dull yellow orange & $10 \mathrm{YR}, 7 / 4$ & 0.001 \\
UFH-10 & Pale yellow & $2.5 \mathrm{Y}, 7 / 4$ & 0.001 \\
UFH-19 & Light gray & $5 \mathrm{Y}, 7 / 2$ & 0.285 \\
UFH-35 & Brownish gray & $10 \mathrm{YR}, 5 / 1$ & 0.750 \\
\hline
\end{tabular}

The study of each energy source consisted of three series of flasks. One series of each energy source was inoculated with $2 \mathrm{ml}$ of freshly collected acid mine drainage (approximately $1 \times 10^{6}$ cells $/ \mathrm{ml}$ ); and another series was inoculated with an active culture of Th. thiooxidans (approximately $2 \times 10^{6}$ cells $/ \mathrm{ml}$ ). The third series, not inoculated, served as a measure of any chemical oxidation that might occur in the system. In both series a bottle containing only the sterile $9 \mathrm{~K}$ salts solution was included as a control. Equilibration and incubation were at $20^{\circ}$ C. Oxygen uptake was recorded usually at 2- to 4-day intervals over an extended period.

\section{EFFECT OF BURIED DEPTH ON THE OXIDATION OF PYRITE}

To determine the effect of buried depth on the oxidation of pyrites, plastic pipe lysimeters (48 inches by 6 inches inside diameter) were employed. The bottom end was closed with a plastic cap provided with an opening through which leachate could escape. The lysimeters were filled with a soil $(\mathrm{pH} \mathrm{6.7)} \mathrm{obtained}$ from an active surface-mining site in Preston County. This soil was described as a Dekalb silt loam, thin variant. Mineralogy of this soil is "mixed" by soil-survey terminology. However, quartz dominated the sand and silt fractions and kaolinite was the predominant clay species. A 1/8-inch thick uniform layer, 130 grams of pyrites $\left(14.34 \% \mathrm{Fe}_{2} \mathrm{O}_{3}, 31.3 \% \mathrm{~S}\right)$ was placed over the entire area inside the lysimeters at specified depths. The particle diameter of the pyritic material ranged from $0.25 \mathrm{~mm}$ to $1.0 \mathrm{~mm}$. The depths were $1 / 2$ inch, 3 inches, 6 inches, 1 foot, 2 feet, 3 feet. A seventh lysimeter containing no pyrite was included as a control. 
A plastic funnel was placed beneath each pyritic layer to collect leachate from the immediate area of the pyritic layer. The funnel was connected to the outside of the column through a short length of surgical tubing attached to a $1 / 4$-inch outside diameter plexiglass tube fixed through the cylinder wall. One liter of distilled water was applied to the surface of each lysimeter at 2-week intervals. Approximately $850 \mathrm{ml}$ of the leachate were recovered from each application. Drainage from the funnels was collected in two-hole stoppered Erlenmeyer flasks $(250 \mathrm{ml})$ connected to the plexiglass drain tube with a short length of Tygon tubing. Evaporation was minimal using this system. The remainder of the drainage passed through the full length of the lysimeter contents and was collected through the base for analysis.

All analyses $\left(\mathrm{Fe}++, \mathrm{Fe}\right.$ total and $\mathrm{SO}_{4}$ ) except $\mathrm{pH}$ were performed using the Hach AC-DR colorimeter. Analyses were performed according to the procedure outlined in the Hach instructional manual. When necessary, dilutions of the leachate were prepared and meter readings were multiplied by the appropriate dilution factor. Ferric-iron content was obtained by difference from the total iron and ferrous iron.

Tests for viable iron oxidizing autotrophic microorganisms in the leachate were made by inoculating complete $9 \mathrm{~K}$ medium with the leachate. The development of the rust-colored precipitate at the surface of the tube was considered to be positive test for the presence of the organisms. The bacteria were not counted.

$\mathrm{pH}$ was determined with a Beckman Zeromatic $\mathrm{pH}$ Meter. Although $\mathrm{pH}$ measures only the active and not the total $\mathrm{H}$ ions, it is commonly used to indicate the acid reaction of soils and in many microbiological studies.

\section{RESULTS}

\section{Acid Production from Selected Mine-spoil Materials}

Table 2 summarizes the results of the study to determine the ability of several mine-spoil materials to produce acid as indicated by $\mathrm{pH}$, when inoculated with T. ferrooxidans. Substantial oxidation occurred with both particle sizes (60- and 140-mesh) of the high sulfur, low-chroma gray sandstone (SS-18, 18\% S). The greater amount of oxidation was obtained with the finer mesh, reaching a final $\mathrm{pH}$ of 1.4 , while the larger particle size gave a final value of 1.8 . The results also indicate that chemical oxidation (nonbiological) also occurred to some extent. Here also, the smaller particle size displayed the greater amount of oxidation. Medium containing the inoculated sandstone samples (SS-18) became yellow during the period of 11 weeks, presumably due to the solubilization of pyrites.

The sandstone containing carbonates $\left(0.9 \% \mathrm{CaCO}_{3}\right.$ equivalent) (UFA-35) displayed an increase in $\mathrm{pH}$ values during the study. The inoculated deep-mine refuse sample remained relatively constant throughout the study, while the uninoculated one showed only a slight increase in $\mathrm{pH}$. This may or may not be 


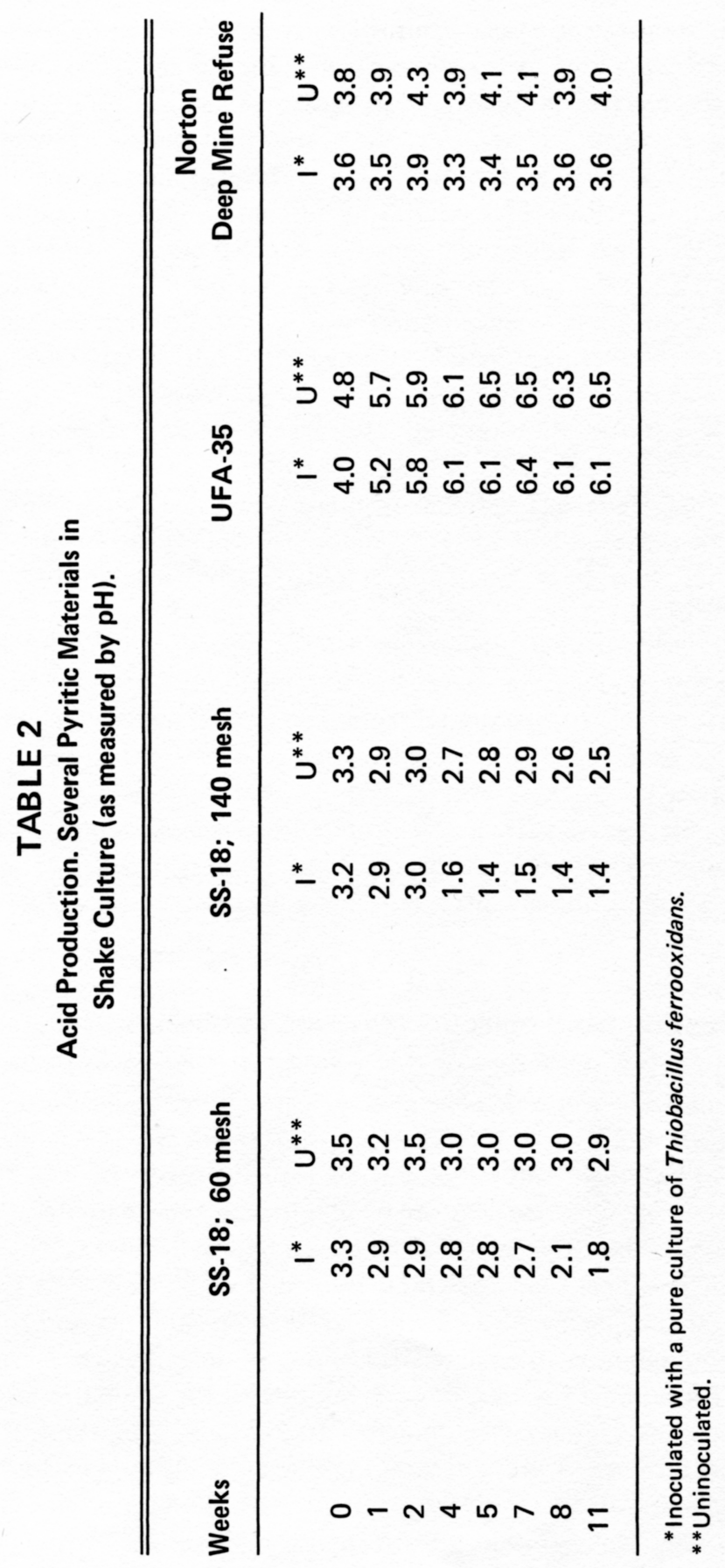


significant. The greatest increase in $\mathrm{pH}$ was recorded for the slightly calcareous sandstone (UFA-35), reaching a final value of 6.1 from the initial 4.0. The uninoculated flask reached a final value of 6.5 .

\section{ACID PRODUCTION FROM CALCAREOUS AND NONCALCAREOUS SANDSTONES}

Further study to determine the effect of carbonates on the microbial oxidation of pyritic mine-spoil materials (Table 3 ) indicated that no appreciable acid production occurred in either series of flasks, i.e., calcareous and noncalcareous sandstones. The lower initial $\mathrm{pH}$ values of the inoculated flasks were due to acid carry-over in the inoculum. The $\mathrm{pH}$ values of the noncalcareous series remained relatively constant over the entire 6-week duration of the study.

The $\mathrm{pH}$ value of the cultures containing calcareous sandstone increased as much as 1.5 units in some cases. The amount of sulfur present did not seem to influence the $\mathrm{pH}$ values. UFA-35, known to contain carbonates, showed the greatest increase in $\mathrm{pH}$, changing from an initial value of 4.9 upon inoculation to 6.4 at the end of a 5 -week incubation period.

Ferrous sulfate, included in this study as a check for viable inoculum, but not shown in Table 3, exhibited an appreciable drop in $\mathrm{pH}$. The oxidation of ferrous sulfate produced a final $\mathrm{pH}$ of 1.9 in the inoculated flask and 2.8 in the uninoculated from an initial $\mathrm{pH}$ of 4.3 .

\section{Manometric Studies}

In all manometric studies, there was more activity in the microbiological systems than in the nonmicrobiological systems. The coal sample ( $4 \% \mathrm{~S})$ exhibited the highest $\mathrm{O}_{2}$ uptake both when inoculated with fresh acid mine drainage or with a pure culture of $T$. ferrooxidans (Figures 1 and 2 ). The activity of the microbiological system was approximately three times that of the nonmicrobiological system when fresh acid drainage was used as the inoculum, and approximately five times greater when a pure culture of $T$. ferrooxidans was used as the inoculum.

When acid drainage was used as the inoculum, the data for the microbiological and nonmicrobiological ferrous sulfate systems were similar. In fact, the oxygen consumption for the nonmicrobiological system exceeded that of the biological system during the early part of the study. The final values were only about 100 units different (Figure 1); however, the final values for the system inoculated with the pure culture were approximately three times greater than that of the uninoculated system (Figure 2).

The low-chroma gray sandstone (SS-18; $18 \%$ S) showed considerably more activity in the inoculated system than in the uninoculated system. The final values for the sandstone were generally equal to or slightly greater than those obtained with crystalline ferrous sulfate. 


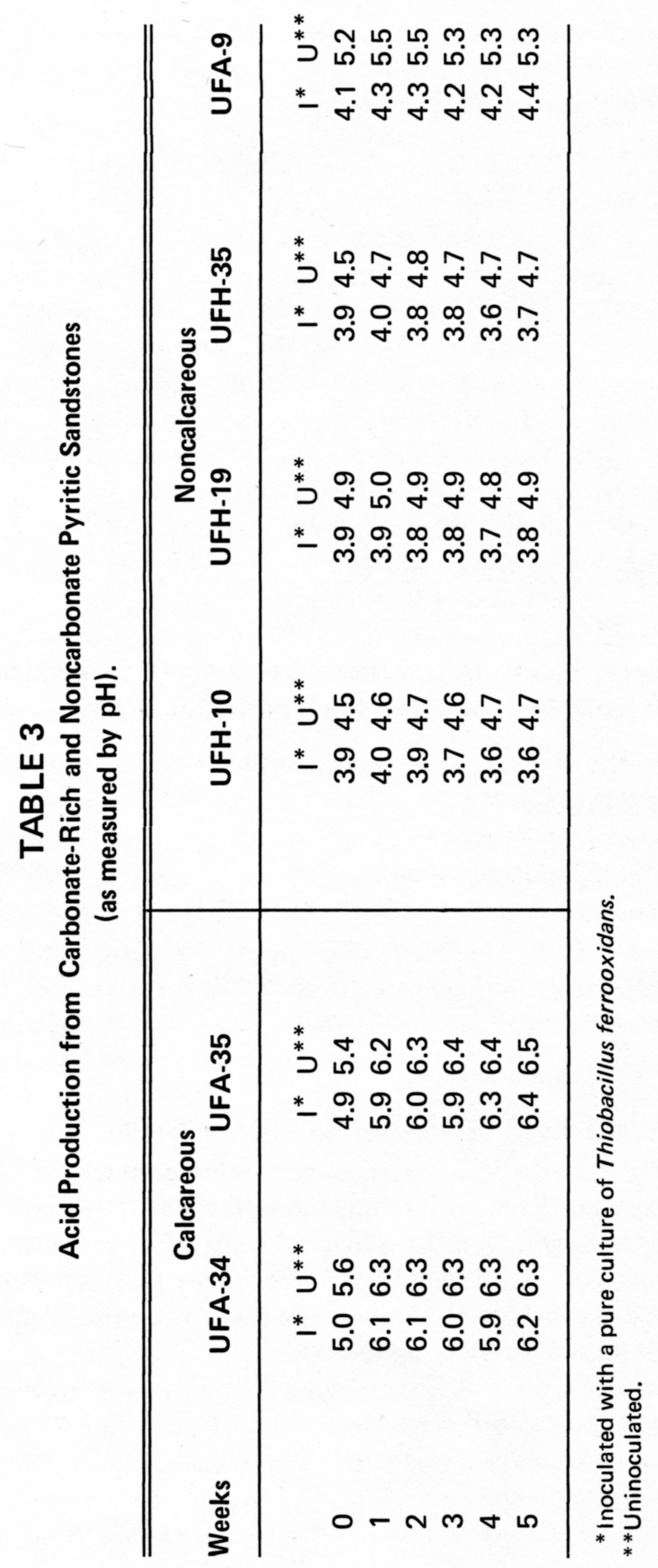




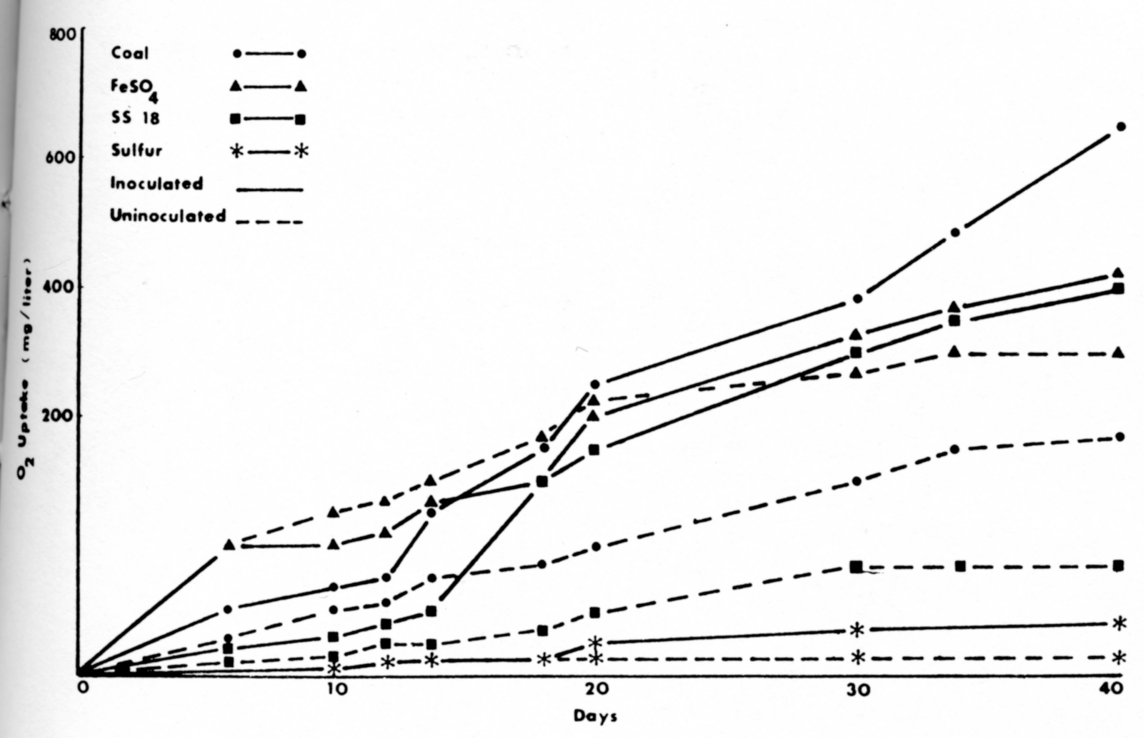

Figure 1. Oxygen uptake with several substrates uninoculated, and inoculated with acid mine drainage. (HACH method)

In all cases, the ferrous sulfate exhibited the greatest amount of nonmicrobiological oxidation. The coal and the sandstone both showed lesser degrees of nonmicrobiological oxidation. In all trials, elemental sulfur was consistently lowest in nonmicrobiological oxidation.

Elemental sulfur also consistently displayed the least amount of activity both in the inoculated and uninoculated systems. The uninoculated sulfur systems did not show any activity at all, the curves being equal to those of the sterile salts solution (not shown) included as a control.

\section{Effect of Burial Depth on the Oxidation of Pyrite}

Tables 4, 5, and 6, and Figure 3 summarize the results of the study to determine the effect of burial depth on the oxidation of pyrite. The data obtained from lysimeters one and two indicated that the oxidation of pyritic material was suppressed when it was buried at a 3-inch depth $(7.6 \mathrm{~cm})$ (Lysimeter 2) as compared to the surface sample (Lysimeter 1). Total iron determinations (Table 4) indicate that considerably more iron became soluble at the surface than at the 3 -inch depth. Figure 3 also indicates that the highest iron concentrations were reached between the third and fourth months of the study. The sulfate content of the leachates corresponded well with the iron values.

Drainage obtained from just below the pyrite layer was characteristically reddish orange in color and of low $\mathrm{pH}$. Drainage obtained from the base of the 


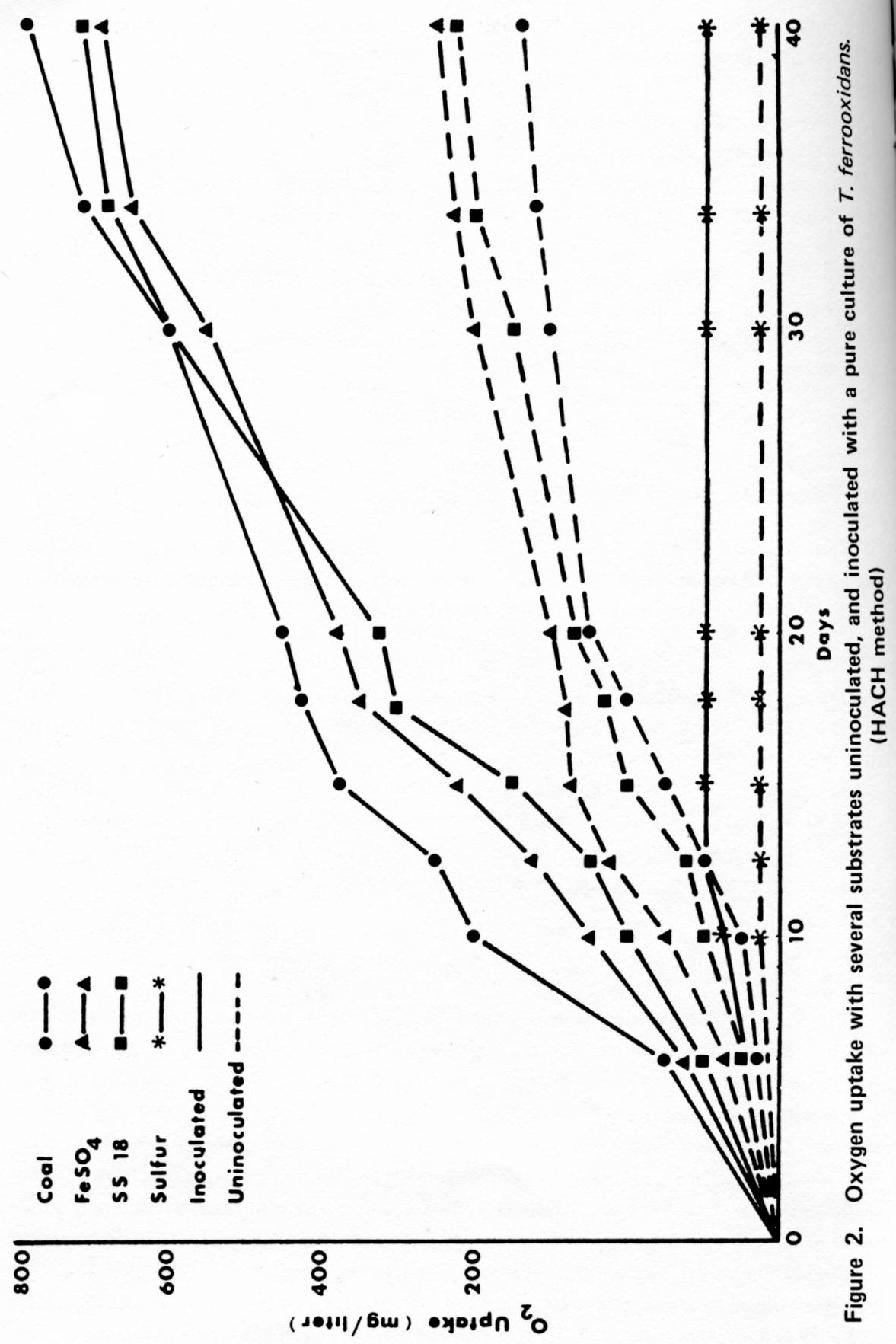


lysimeters until about the eighth week was nearly always colorless, of neutral pH (Table 5), and contained little or no iron. After the eighth week, the iron content of the drainage from the base of the lysimeters began to increase. This drainage also contained a precipitate that had the appearance of iron hydroxide.

"The sulfate content (Table 6) of the leachates also was reduced but not absent after passing through the remainder of the column. The amount of iron in the leachates from the bottom of the lysimeter also was higher where the pyrite was placed nearer to the bottom of the column. Viable autotrophic iron-oxidizing bacteria were recovered from the leachate throughout the study.

Except for lysimeters one and two and seven, the data are incomplete. The funnels installed to collect the leachate either became clogged or the leachate passed them.

\section{DISCUSSION}

Certain pyritic mine spoil materials will produce acidic products under the influence of the iron-oxidizing autotrophic bacterium Thiobacillus ferrooxidans. Particle size apparently exerts an influence upon acid production; the smaller the size the more sites for bacterial attachment if the "direct-contact mechanism" (10) of bacterial pyrite oxidation is operational in this instance. Acidity also was generated earlier in the study with the smaller particle size.

There may exist a level of pyrite in the sandstones below which significant acid production does not occur, or if it does occur, it is readily neutralized by other sandstone constituents, and not detectable in our system. Throughout the study the only low-chroma sandstone to show appreciable acid production was the SS-18 sample which contained 18 per cent sulfur (present as observable pyrite). This is a considerably greater quantity than the 0.75 per cent sulfur content of the UFH-35 sample which did not produce a significant amount of acid. The UFH-35 sample had the highest sulfur content of all the sandstone samples tested with the exception of the SS-18 sample.

It is to be pointed out that the 0.75 per cent sulfur content of the UFH-35 sample is considered to be quite a high value among the various sandstones overlying the Upper Freeport coal seam being mined. The 18 per cent sulfur content of the SS-18 sample is abnormally high.

Evidence for the influence of carbonates against the production of acid from the sandstones can be seen in the results of the study of the oxidation of carbonate-rich vs. noncarbonate sandstones (Table 3). No acid was produced from the slightly calcareous pyritic sandstones. The presence of the alkaline carbonates causes a rise in the $\mathrm{pH}$, a condition that is adverse to the growth of the bacteria involved in the acid production. Although these bacteria are tolerant of near-neutral pH levels they seldom display any activity above a pH of 5.0. 


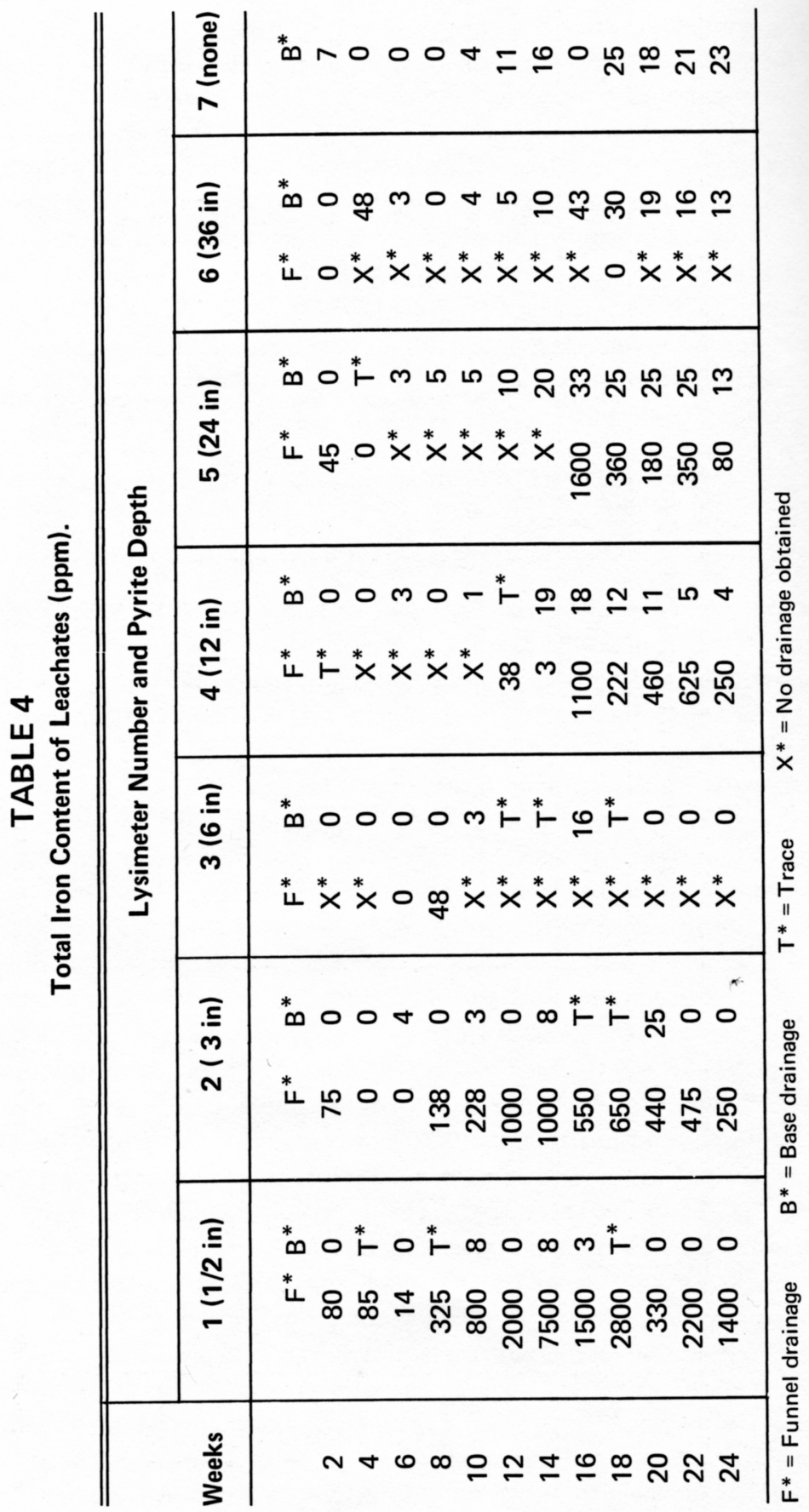




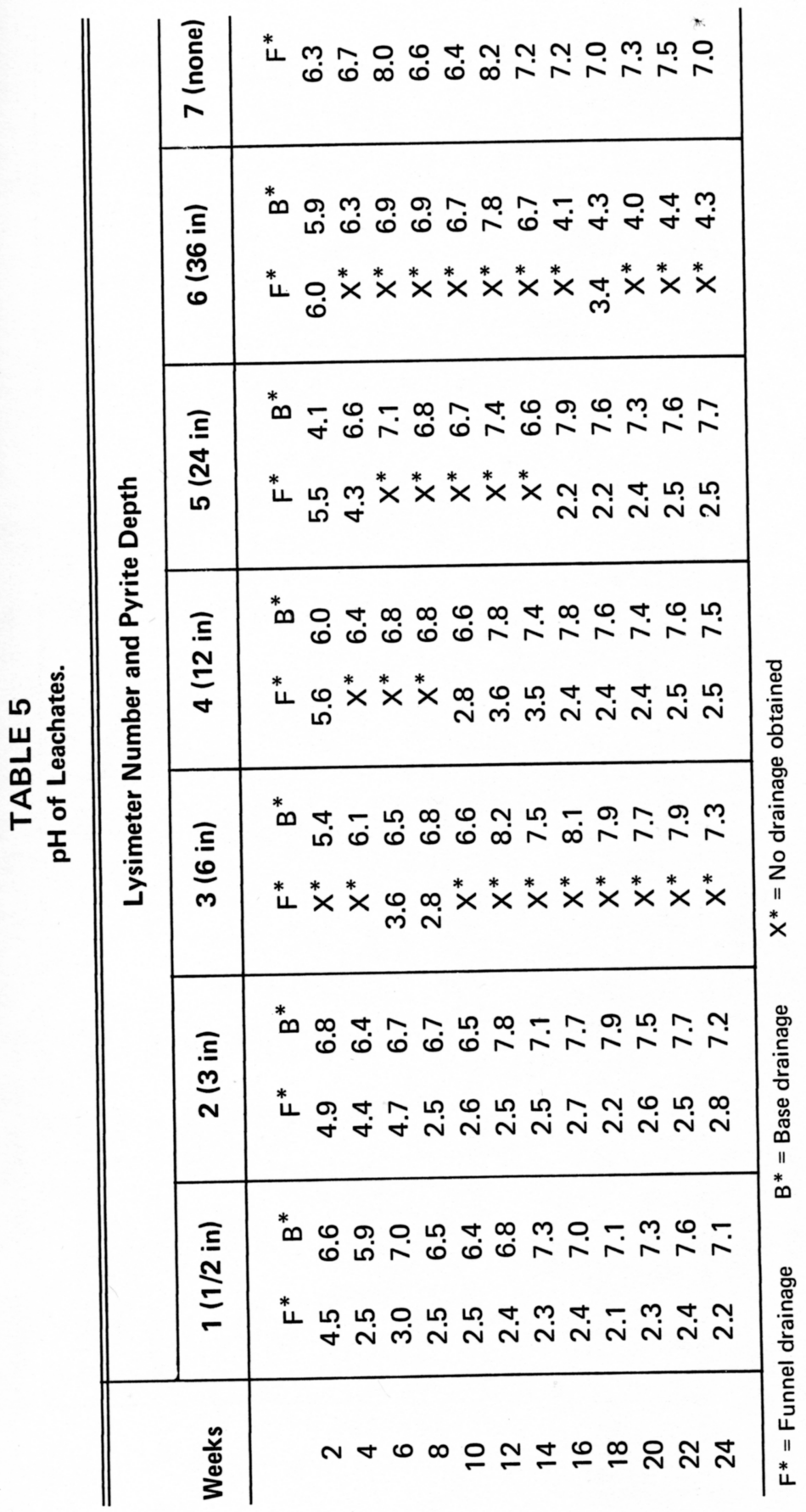




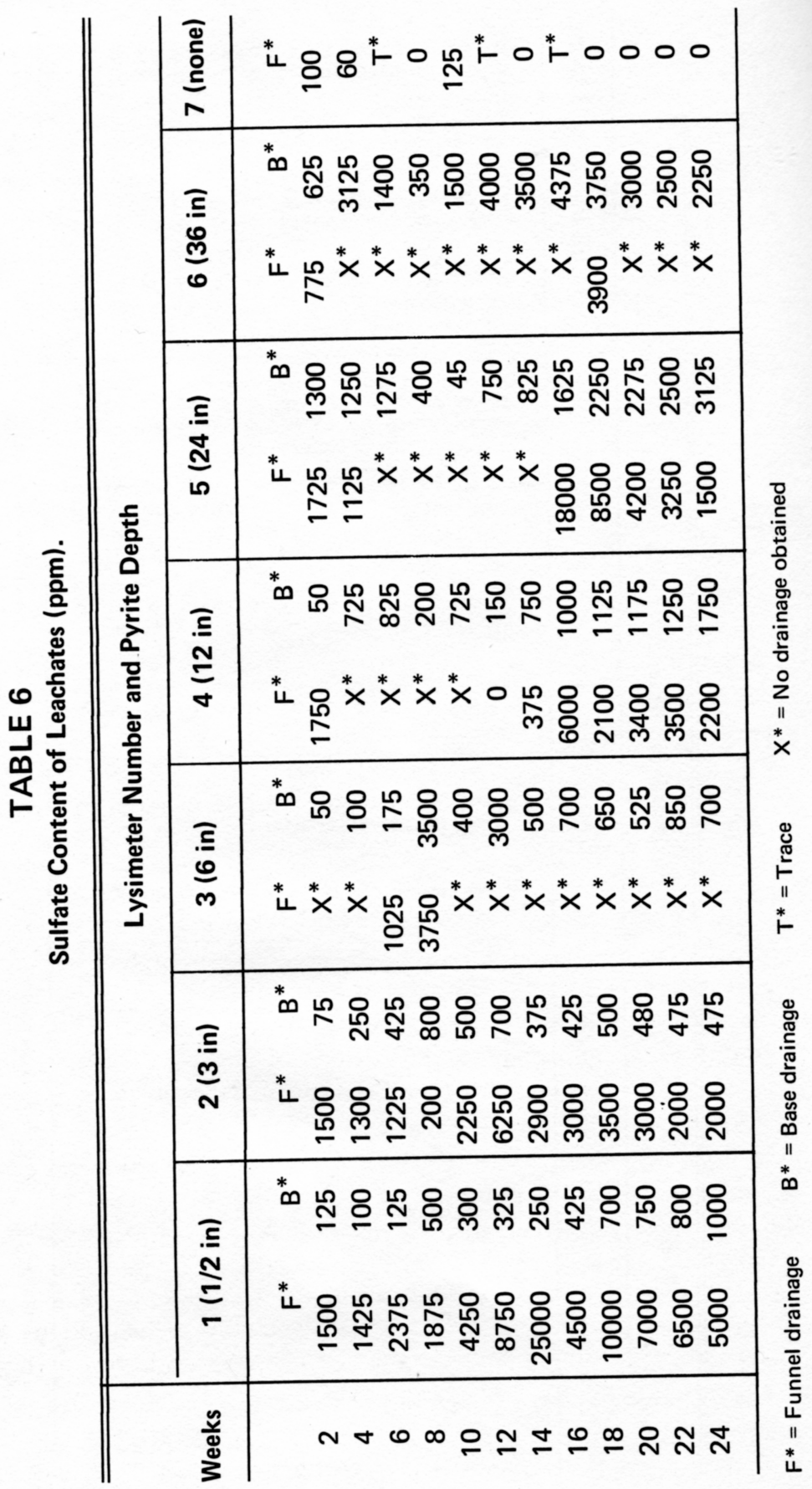




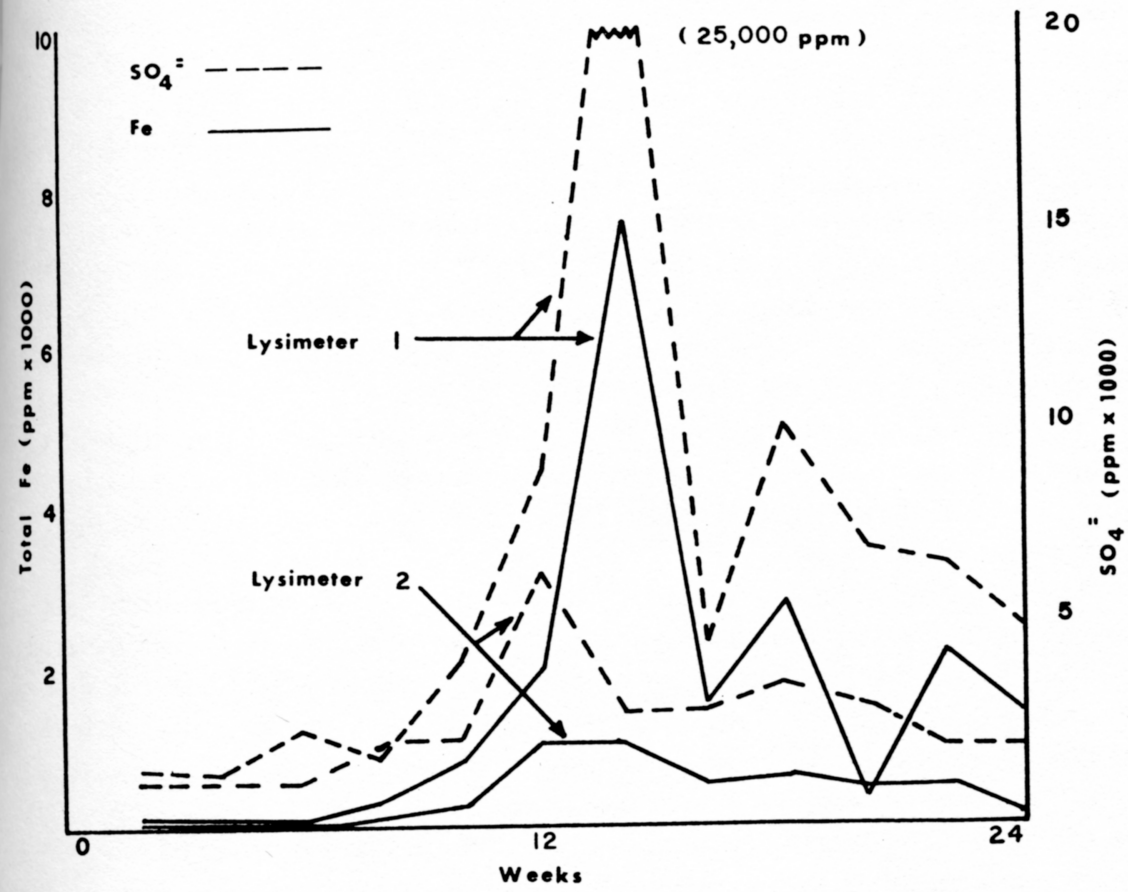

Figure 3. Iron and sulfate content of leachates from the funnels of lysimeters one and two.

The results of this study are in accord with those of Silverman (10) who reported resistance of a pyrite sample containing carbonates to microbial oxidation. He reported that the removal of the carbonates by $\mathrm{HC} 1$ treatment rendered the sample susceptible to attack by the microorganisms.

These implications are of importance in considering reclamation practices. Hence the liming of an acid spoil is beneficial not only in that it raises the soil $\mathrm{pH}$ to a level acceptable for plant growth, but it also creates conditions unfavorable to the development of the iron- and sulfur-oxidizing bacteria responsible for the production of acid.

Burial depth has an influence upon the oxidation of the pyritic materials. The bacteria involved in the formation of the acid are strictly aerobic; therefore the placement of oxidizable substrates as far below the surface as is possible during regrading will eliminate or greatly reduce the microbial formation of acidic end-products. It is likely that anaerobic (reducing) conditions would be established at the greater depths.

The drainage from the base of the lysimeters contained little or no iron. In explanation of this, it is probable that the iron had precipitated out of the 
solution within the column upon reaching an area of higher $\mathrm{pH}$, or replaced the exchangeable bases of the soil. The sulfate was apparently in the form of a near-neutral salt as is evidenced by the relatively high $\mathrm{pH}$ values of the base drainage. There is evidence that the soil eventually becomes saturated with iron since the iron began to increase in the drainage recovered from the base of the column. The higher iron content of the bottom drainage when the pyrite was buried deeply is probably due to the fact that there was not much soil below the pyrite area for the solution to react with as it passed down through the lysimeter. Regardless, the depth at $\mathbf{3 6}$ inches would be too deep to have any influence upon the average plant growth.

The mine spoil materials used in this study represent but a fraction of the many materials that could be investigated; however, they are representative of the types of materials that must be dealt with during the reclamation of surface-mined lands.

The acid-producing nature of the mine spoil materials tested warrants some special handling during their removal and replacement. Highly pyritic materials that are found through core sampling and subsequent chemical analyses should be segregated during the removal of the overburden so that they may be buried as deeply as possible when the mine spoils are replaced. Applying lime to the spoil piles during standing and as they are replaced could prove to be beneficial to the abatement of acid production. Further studies on the effect of carbonates on the autotrophic iron-oxidizing bacteria might lead to some idea of the mechanism of inhibition of pyrite oxidations, and a possible means for controlling the activities of these microorganisms.

Treatment of the spoil materials should be initiated before the problem of acid production becomes firmly established, i.e., before the organisms reach significant numerical levels. If surface-mined lands are to be returned as nearly as possible to their former or even better conditions, intensive practice of the above recommendations should be included as part of the reclamation program. 


\section{LITERATURE CITED}

1. Colmer, A. R., and M. E. Hinkle. 1947. The role of microorganisms in acid mine drainage. A preliminary report. Science 106:253-256.

2. Colmer, A. R., K. L. Temple, and M. E. Hinkle. 1950. An iron oxidizing bacterium from the acid drainage of some bituminous coal mines. J. Bact. 59:317-328.

3. Funk, D. T. 1962. A revised bibliography of strip mine reclamation. USDA Forest Service, Central States Expt. Sta., Columbus, Ohio.

4. Kelly, D. P., and O. H. Tuovinen. 1972. Recommendations that the names Ferrobacillus ferrooxidans Leathen and Braley and Ferrobacillus sulfooxidans Kinzel be recognized as synonyms of Thiobacillus ferrooxidans Temple and Colmer. Intern. J. Syst. Bact. 22:170-172.

5. Kuznetsov, S. I., M. V. Ivanov, and N. N. Lyalikova. 1963. Introduction to geological microbiology. McGraw-Hill Book Co., Inc., New York. 245 pp.

6. Leathen, W. W., and S. A. Braley. 1953. A new iron oxidizing bacterium: Ferrobacillus ferrooxidans. Bacteriol. Proc. 44.

7. Martin, E. J., and R. D. Hill. 1968. Mine drainage research program of the F.W.P.C.A., Second Symposium on the Coal Mine Drainage:46-63.

8. Mellinger, R. H., F. W. Glover, and J. C. Hall. 1966. Results of revegetation of strip mine spoil by soil conservation districts of West Virginia. W.Va. Agr. Expt. Sta. Bull. $540.18 \mathrm{pp}$.

9. Silver, M. 1970. Oxidation of elemental sulfur compounds and $\mathrm{CO}_{2}$ fixation by Ferrobacillus ferrooxidans (Thiobacillus ferrooxidans). Can. J. Microbiol. 16:845-849.

10. Silverman, M. P. 1967. Mechanism of bacterial pyrite oxidation. J. Bact. 94:1046-1501.

11. Silverman, M. P., and H. L. Ehrlich. 1964. Microbial formation and degradation of minerals. Advan. Appl. Microbiol. 6:153-206.

12. Silverman, M. P., and D. G. Lundgren. 1958. Studies on the chemoautotrophic iron bacterium Ferrobacillus ferrooxidans. I. An improved medium and harvesting procedure for securing cell high yields. J. Bact. 77:642-647.

13. Temple, K. L., and A. R. Colmer. 1951. The autotrophic oxidation of iron by a new bacterium: Thiobacillus ferrooxidans. J. Bact. 62:605-611.

14. Temple, K. L., and E. Delchamps. 1953. Autotrophic bacteria and the formation of acid in bituminous coal mines. Appl. Microbiol. 1: No. 5.

15. Unz, R. F. and D. G. Lundgren. 1961. A comparative nutritional study of three chemoautotrophic bacteria: Ferrobacillus ferrooxidans, Thiobacillus ferrooxidans, and Thiobacillus thiooxidans. Soil Science 92:302-313.

16. West Virginia University. 1971. Mine spoil potentials for water quality and controlled erosion. Water Pollution Control Research Service 14010 EJE. December, 1971. Environmental Protection Agency, Washington, D.C.

17. Wilson, H. A. 1965. The microbiology of strip-mine spoil. W.Va. Agr. Expt. Sta. Bull. 506T. $44 \mathrm{pp}$. 
[Blank Page in Original Bulletin] 
[Blank Page in Original Bulletin] 
[Blank Page in Original Bulletin] 